\title{
IMPLEMENTASI DIRECT SHIPMENT PADA APLIKASI DISTRIBUSI ABATE (Studi Kasus RW. 05, Lenteng Agung)
}

\author{
Syasya Adinta Cipta Sari \\ Program Studi Teknik Informatika, Fakultas Teknik dan Ilmu Komputer, \\ Universitas Indraprasta PGRI \\ Jalan Raya Tengah No 80, Kelurahan Gedong, Pasar Rebo, Jakarta Timur \\ syasyaadintac@gmail.com
}

\begin{abstract}
Abstrak
Sistem distribusi yang baik menjadi kunci utama dalam berbagai kegiatan yang berhubungan dengan pengiriman maupun penerimaan barang. Jalur distribusi tidak hanya mengandalkan konsep semata, melainkan juga butuh pendataan yang jelas dan rinci. Dalam penelitian ini, proses distribusi bubuk abate yang diterapkan kader Jumantik masih tergolong sederhana yaitu bubuk abate langsung didistribusikan dari Puskesmas ke Petugas Jumantik untuk diberikan kepada warga yang rumahnya berstatus positif jentik nyamuk Aedes aegypti. Maka dalam perancangan aplikasi pendistribusian abate ini, penulis menggunakan salah satu konsep dalam distribusi yaitu metode direct shipment. Metode direct shipment dipilih karena metode ini memfokuskan pendistribusian secara langsung tanpa adanya titik - titik penyimpanan sementara. Tujuan yang ingin dicapai dari penelitian ini ialah merancang suatu aplikasi distribusi bubuk abate dengan menerapkan metode direct shipment, dimana proses distribusi abate menjadi lebih tepat sasaran bagi warga yang rumahnya berstatus positif jentik nyamuk. Sementara, permasalahan yang dapat timbul dari direct shipment ialah biaya transportasi yang cenderung lebih besar. Serta aplikasi ini hanya mencatat distribusi abate dari petugas ke warga.
\end{abstract}

Kata Kunci : Distribusi, Direct Shipment, Aplikasi, Bubuk Abate.

\begin{abstract}
Good distribution system is the main key in various activities related to the delivery and receipt of goods. Distribution channels not only rely on concepts alone, but also need clear and detailed data collection. In this study, the distribution process of abate powder applied by Jumantik was still relatively simple, the abate powder was directly distributed from the Puskesmas to Jumantik Officers to be given to residents whose houses were positive for Aedes aegypti mosquito larvae. So in designing this abate distribution application, the author uses one of the concepts in distribution, that's the direct shipment method. The direct shipment method was chosen because this method focuses on direct distribution without any temporary storage points. The aim of this study is to design an application for distribution of abate powder by applying the direct shipment method, where the abate distribution process becomes more targeted for residents whose houses are positive for mosquito larvae. Meanwhile, problems that can arise from direct shipments are transportation costs which tend to be higher. And this application only records the distribution of abate from officers to residents.
\end{abstract}

Keyword : Distribution, Direct Shipment, Application, Abate Powder.

\section{PENDAHULUAN}

Dalam penelitian (Fitrianingsih, 2019), dikatakan bahwa setiap tahun kejadian penyakit demam berdarah dengue (DBD) di Indonesia cenderung meningkat pada pertengahan musim penghujan sekitar bulan Januari dan cenderung turun pada bulan Februari hingga ke penghujung tahun. Sepanjang Januari 2016 Direktorat Pengendalian Penyakit Tular Vektor dan Zoonosis Kementerian Kesehatan mencatat 3.298 kasus DBD dengan jumlah kematian sebanyak 50 kasus di Indonesia. Penyebaran penyakit DBD terkait erat dengan kepadatan penduduk, mobilitas, perilaku masyarakat, kondisi iklim, serta tingginya perkembangbiakan nyamuk penular DBD atau yang dikenal dengan nyamuk Aedes aegypti. Upaya penanggulangannya ialah dengan dibentuknya Kelompok Kerja Operasional Demam Berdarah Dengue (Pokjanal DBD) dan kegiatan Juru Pemantau Jentik (Jumantik). Menurut (Porogoi et al., 2019), Juru Pemantau Jentik (Jumantik) merupakan kader yang berasal dari masyarakat di suatu daerah, yang pembentukannya dan 
pengawasan kinerja bertanggungjawab sepenuhnya oleh pemerintah kabupaten/kota. Namun meski telah di bentuk Jumantik, angka penyebaran DBD masih belum dapat ditekan sepenuhnya. Salah satunya karena distribusi abate yang kurang tepat sasaran.

Menurut (Karundeng et al., 2018), Distribusi atau place adalah proses menyalurkan barang dan jasa dari produsen kepada target konsumen. Dari saluran distribusi untuk consumer product market, perantara yang langsung berhubungan dengan konsumen adalah retailer atau pengecer. Dalam distribusi produk akan terbentuk suatu rantai atau saluran yang dilewati oleh produk yang disebut saluran distribusi. Secara garis besar, strategi distribusi dapat dibedakan menjadi tiga, yaitu cross docking (yang biasa disebut sebagai just-in-time distribution), direct shipment, dan warehousing.

Pada penelitian ini penulis menggunakan metode direct shipment yang merupakan strategi dengan pelayanan point-to-point sehingga pabrik langsung mengirimkan barang ke retail (Soetanto, 2015). Dimana metode tersebut sesuai dengan permasalahan distribusi bubuk abate di Jumantik RW. 05, Kelurahan Lenteng Agung, Kecamatan Jagakarsa, Jakarta Selatan, DKI Jakarta. Proses distribusi bubuk abate yang diterapkan petugas Jumantik masih tergolong sederhana yaitu bubuk abate langsung didistribusikan dari Puskesmas ke Petugas Jumantik untuk diberikan kepada warga yang rumahnya berstatus positif jentik nyamuk Aedes aegypti. Oleh karena itu, penulis menggunakan metode direct shipment untuk mencapai tujuan dari penelitian ini yaitu merancang suatu aplikasi distribusi bubuk abate dengan menerapkan metode direct shipment, dimana proses distribusi abate menjadi lebih tepat sasaran bagi warga yang rumahnya berstatus positif jentik nyamuk.

\section{PENELITIAN RELEVAN}

Beberapa penelitian yang relevan dengan Implementasi Metode Direct Shipment Pada Aplikasi Distribusi Bubuk Abate antara lain, penelitian yang dilakukan (Abdul \& Evitha, 2019), yang berjudul Desain Jaringan Distribusi Berbasis E-Business Pada Sistem Rantai Pasok. Pada jurnal ini, dapat ditentukan model jaringan distribusi yang baik dengan pendekatan desain jaringan distribusi dan memberikan kualitas pelayanan yang lebih baik melalui jangka waktu pengiriman peralatan dan material sampai di lokasi konsumen, tetapi juga penekanan biaya yang dapat memberikan harga yang lebih bersaing kepada calon calon konsumen. Dari 6 desain jaringan distribusi, pendekatan model jaringan last mile delivery dan carrier delivery, tepat diterapkan dalam jaringan distribusi e-commerce. Perusahaan internasional yang telah menerapkan model jaringan last mile delivery dan carrier delivery adalah Amazon.

Dan yang terakhir penelitian (Kurniawan et al., 2019), yang berjudul Analisis Kinerja Distribusi Logistik Pada Pasokan Barang Dari Pt. Surya Pamenang Ke Konsumen. Kebijakan pengendalian manajemen distribusi logistic akan berpengaruh dengan terhadap meningkat performa kinerja perusahaan dalam mendistribusikan permintaan dari produsen kekonsumen pelanggan dan mengatur persediaan produk di pusat distribusi. Dilihat dari segi kinerja menejemen PT. Surya Pamenang dalam pemenuhan kebutuhan sudah optimal. Akan tetapi dalam mendukung kinerja manajemen rantai pasokan yang tidak terlepas dari pengaruh lokasi pusat distribusi terhadap jarak Pendistribusian, kelancaran transportasi dalam pendistribusian ke konsumen serta ketersediaan produk di pusat distribusi untuk memenuhi permintaan dari setiap konsumen perlu dievaluasi kembali. Dengan adanya penilitian ini diharpakan dapat membatu dalam mengatasi permasalahan permasalahan yang di hadapi PT. Surya Pamenang. Penelitian ini menyimpulakan bahwa perusahan dapat lebih efisien dan efektif dalam meminimalisir dari resiko yang dapat terjadi bagi perusahaan. Kinerja dari manajemen logistik mendukung peningkatan yang positif bagi perusahaan.

\section{METODE PENELITIAN}

Menurut (Putri et al., 2018), saluran distribusi adalah perantara-perantara, para pembeli dan penjual yang dilalui oleh perpindahan barang baik fisik maupun perpindahan milik sejak dari produsen hingga ke tangan konsumen. Suatu perusahaan di dalam mendistribusikan barangnya dapat menggunakan salah satu atau lebih dari cara penyaluran. Secara terperinci, kegiatan yang ada dalam distribusi fisik dapat dibagi kedalam lima macam yaitu (Khiram \& Irawati, 2017):

1. Penentuan lokasi persediaan dan sistem penyimpanannya:

a. Penentuan lokasi penyediaannya 
b. Sistem penyimpanan persediaan.

2. Sistem penanganan barang yang dapat digunakan antara lain :

a. Paletisasi

b. pengemasan.

3. Sistem pengawasan persediaan

4. Prosedur memproses pesanan

5. Pemilihan metode pengangkutan

Pihak produsen harus menentukan apakah akan mendistribusikan produknya secara terpusat hanya pada beberapa daerah saja atau tersebar ke seluruh daerah. Selain itu, produsen juga harus memutuskan apakah akan memasarkan produknya secara langsung atau melalui perantara (Nurisusilawati \& Subagyo, 2016). Pada distribusi abate di Jumantik RW. 05, Kel, Lenteng Agung, jalur distribusi yang digunakan adalah distribusi langsung, yaitu distribusi yang digunakan oleh produsen untuk menjual barang langsung ke konsumen dan tidak memiliki perantara.

Teknik pengumpulan data berupa suatu pernyataan (statement) tentang sifat, keadaan, kegiatan tertentu dan sejenisnya. Pengumpulan data dilakukan untuk memperoleh informasi yang dibutuhkan dalam rangka mencapai tujuan penelitian (Kasengkang et al., 2016). Pada penelitian ini penulis menggunakan metode wawancara dengan Petugas Koordinator RW dan Petugas Koordinator RT Jumantik RW. 05, serta melakukan observasi langsung mengenai bagaimana proses pendistribusian yang diterapkan oleh Jumantik RW. 05.

\section{HASIL DAN PEMBAHASAN}

Setelah penulis melakukan pengamatan, maka terdapat beberapa permasalahan pada proses distribusi abate di Jumantik RW. 05, Kel. Lenteng Agung, yaitu pendistribusian bubuk abate yang kurang tepat sasaran dikarenakan pendataan masih dilakukan secara manual, sehingga data tidak tercatat secara menyeluruh yang menyebabkan permasalahan pada proses pendistribusian. Oleh sebab itu, penulis membuat aplikasi Data ABJ dan Distribusi Bubuk Abate dengan menerapkan metode direct shipment, yang bertujuan untuk menyelesaikan permasalahan pada jalur distribusi bubuk abate dengan membuat semua data dapat tercatat di aplikasi, sehingga distribusi bubuk abate dapat tepat sasaran bagi warga yang rumahnya berstatus positif jentik nyamuk.

Penulis membuat rancangan Diagram Nol dan ERD Aplikasi seperti pada penelitian (Solikhin et al., 2018), untuk mengimplementasikan metode direct shipment pada aplikasi Data ABJ dan Distribusi Abate sebagai berikut:

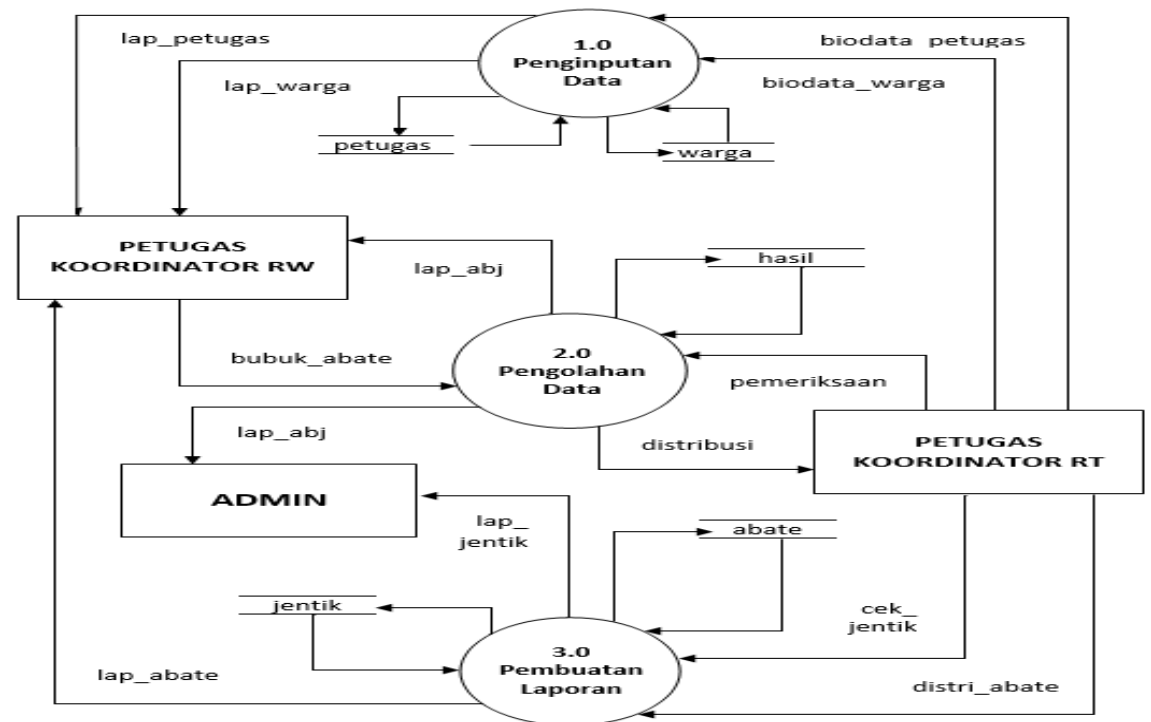

Gambar 1. Diagram Nol Aplikasi 


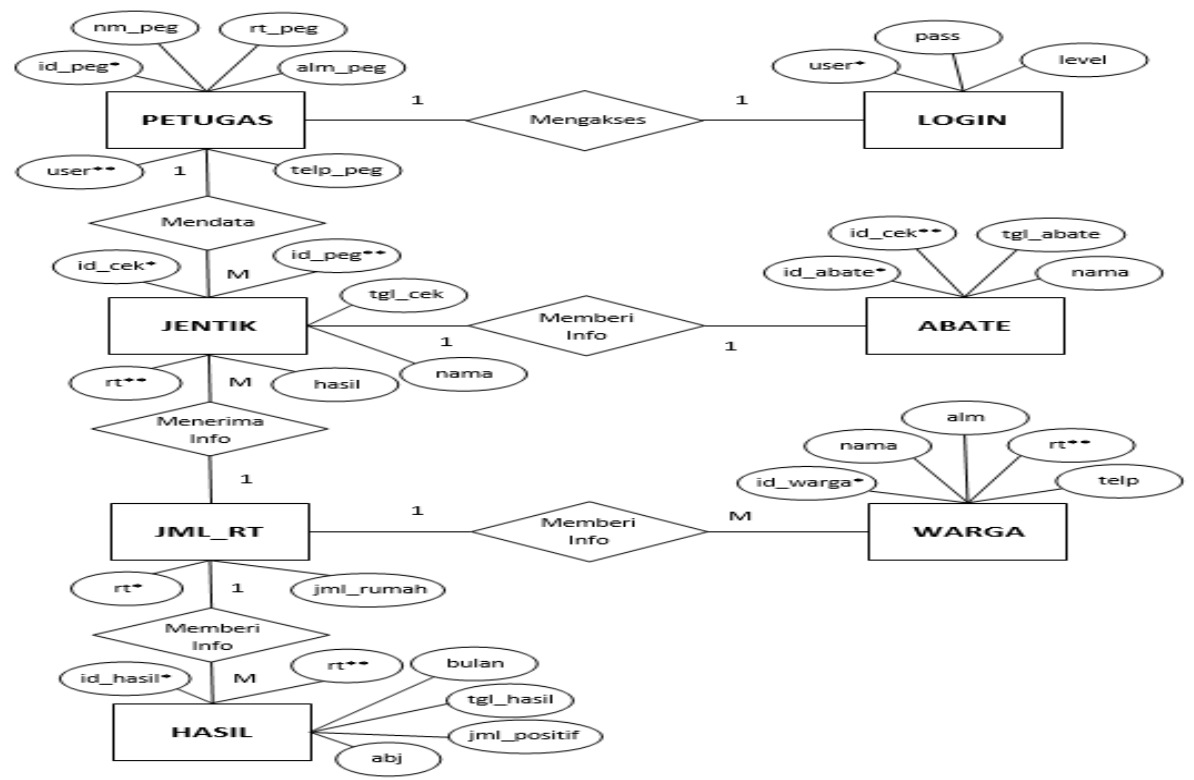

Gambar 2. ERD Aplikasi

Selanjutnya pada pembuatan aplikasi, penulis menerapkan metode direct shipment pada relasi antara tabel jentik dan tabel abate di database yang dibuat saling berkaitan satu sama lain. Seperti yang terlihat pada ERD diatas, primary key id_cek* pada tabel jentik akan digunakan kembali oleh tabel abate dengan menjadikannya foreign key id_cek**. Untuk lebih jelasnya dapat dijabarkan seperti pada penelitian yang dilakukan (Julaeha et al., 2020):

Jentik $=\{\underline{\text { id_cek }}$, tgl_cek, nama, rt, hasil, i_d_peg***. $\}$

Abate $=\left\{\right.$ id_abate*, id_cek ${ }_{--.}^{* *}$ tgl_abate, nama $\}$

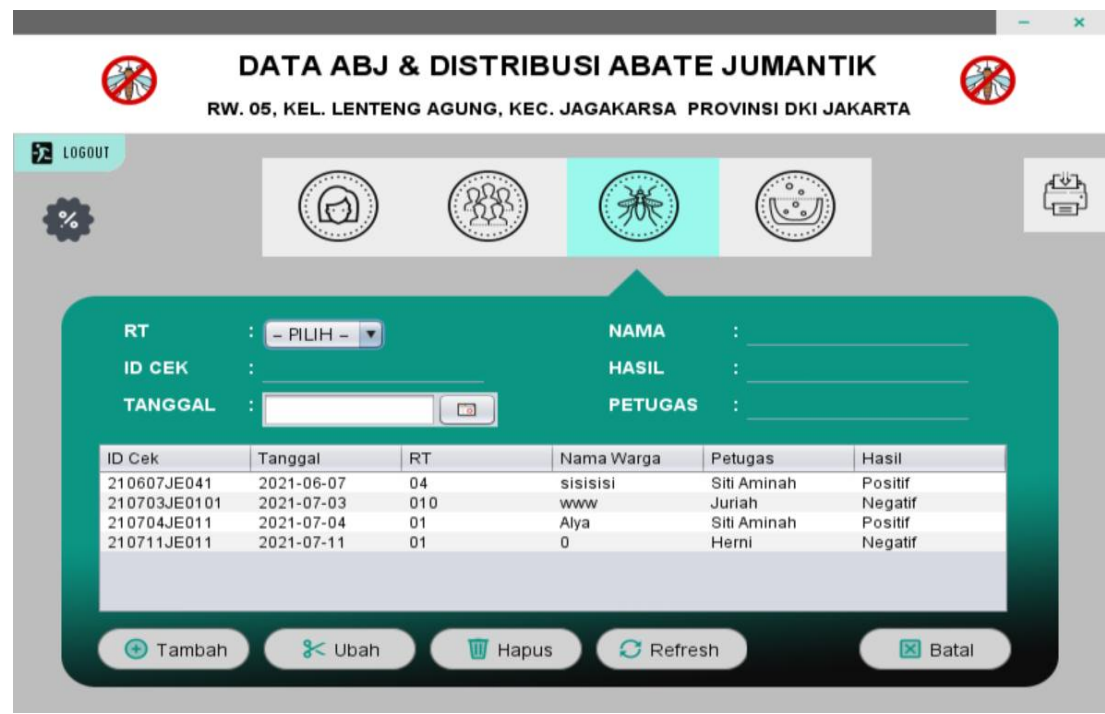

Gambar 3. Tampilan Data Jentik Pada Aplikasi

Sedangkan pada tampilan aplikasi, penulis terlebih dahulu membuat tampilan Data Jentik yang berisi data - data pemeriksaan rumah warga yang berstatus positif atau negatif jentik. 


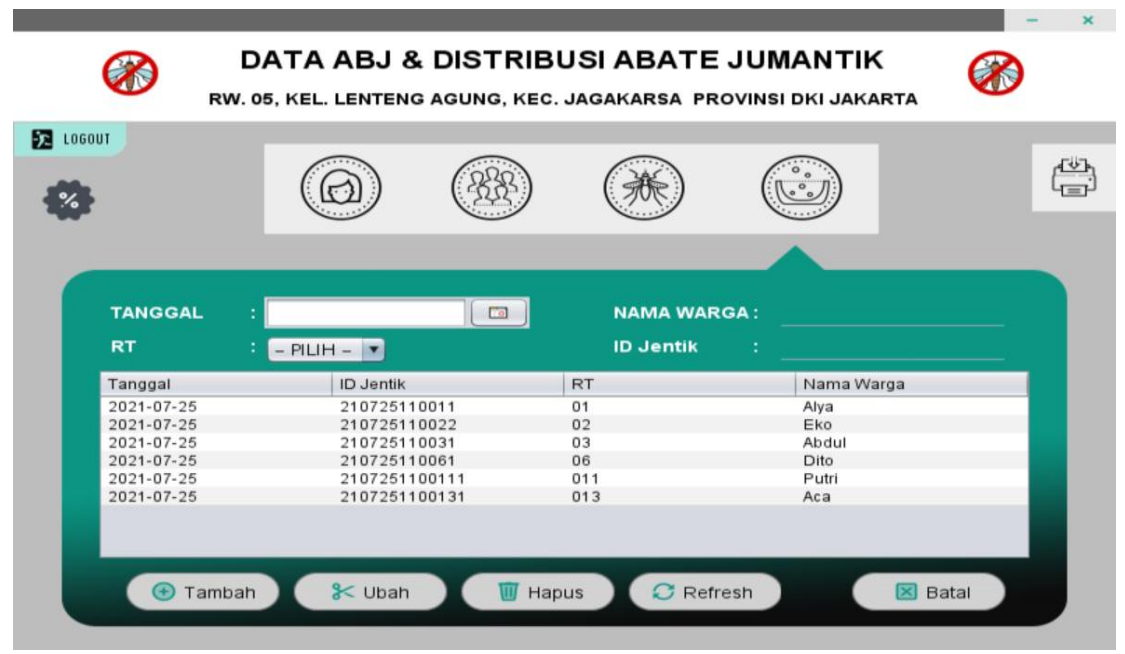

Gambar 4. Tampilan Data Abate Pada Aplikasi

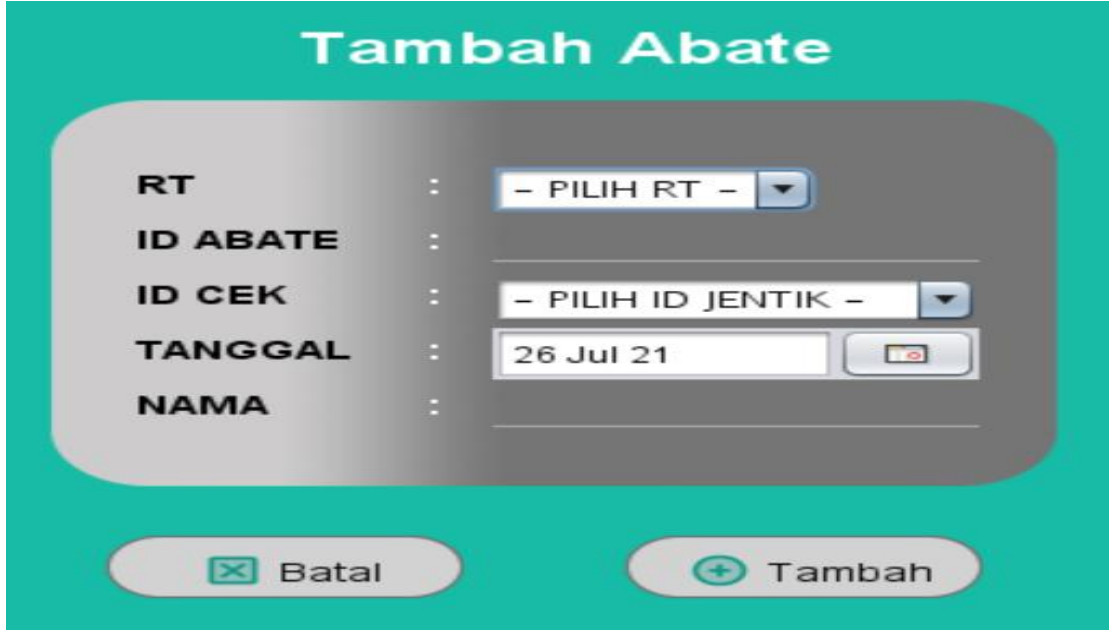

Gambar 5. Tampilan Tambah Data Abate Pada Aplikasi

Selanjutnya, data berupa ID Cek dari warga yang rumahnya berstatus positif jentik akan ditampilkan pada Tampilan Data Abate dan Tampilan Tambah Data Abate pada aplikasi dengan nama ID Jentik. Dengan dibuatnya relasi ini, maka ID Jentik yang ditampilkan hanya warga yang rumahnya berstatus positif jentik.

\section{SIMPULAN}

Berdasarkan hasil penelitian yang dilakukan penulis yang berjudul Implementasi Direct Shipment Pada Aplikasi Distribusi Abate (Studi Kasus: RW.05, Lenteng Agung), didapati bahwa jalur distribusi bubuk abate yang dilakukan Petugas akan menjadi lebih jelas dan terarah dengan diterapkannya metode Direct Shipment, karena data hasil pemeriksaan jentik pada rumah warga tercatat dengan lengkap. Dengan dibuatnya relasi antara tabel jentik dan tabel abate pada database, maka ketika Petugas akan melakukan proses distribusi bubuk abate hanya akan ditampilkan data ID Cek Jentik yang berstatus positif. Sehingga pendistribusian bubuk abate menjadi lebih tepat sasaran bagi warga yang rumahnya berstatus positif jentik.

\section{DAFTAR PUSTAKA}

[1] Abdul, F. W., \& Evitha, Y. (2019). Desain Jaringan Distribusi Berbasis E-Business Pada Sistem Rantai Pasok. Jurnal Logistik Indonesia, 3(1), 39-51. https://doi.org/10.31334/jli.v3i1.349

[2] Fitrianingsih. (2019). Survey Jentik Nyamuk Dan Pemberian Bubuk Abate Di Bak Mandi Warga Rt 03 Rw 03 Desa Mrican Kecamatan Sragi Kabupaten Pekalongan. Journal Bio Education, 4(1), 33-40.

[3] Julaeha, S., Kustian, N., Parulian, D., Data, E., Relasi, D., \& Relationship, T. (2020). Pemetaan Tabel Relationship Dalam Visualisasi. String, 5(2), 126-133. 
[4] Karundeng, T., Mandey, S., \& Sumarauw, J. (2018). Analisis Saluran Distribusi Kayu (Studi Kasus Di Cv. Karya Abadi, Manado). Jurnal EMBA: Jurnal Riset Ekonomi, Manajemen, Bisnis Dan Akuntansi, 6(3), 1748-1757. https://doi.org/10.35794/emba.v6i3.20444

[5] Kasengkang, R. A., Nangoy, S., \& Sumarauw, J. (2016). Analisis Logistik (Studi Kasus pada Pt. Remenia Satori Tepas-Kota Manado). Jurnal Berkala Ilmiah Efisiensi, 16(01), 750-759.

[6] Khiram, H., \& Irawati, W. (2017). Analisis Perencanaan Sistem Distribusi pada PT. Lafarge Cement Indonesia Aceh Besar. Jurnal Ilmiah Mahasiswa Ekonomi Manajemen, 2(1), 118-134. http://www.jim.unsyiah.ac.id/EKM/article/viewFile/2130/3263

[7] Kurniawan, R., Santoso, H., \& Komari, A. (2019). Analisis Kinerja Distribusi Logistik Pada Pasokan Barang Dari Pt. Surya Pamenang Ke Konsumen. JURMATIS: Jurnal Ilmiah Mahasiswa Teknik Industri, 1(2), 81-95. https://doi.org/10.30737/jurmatis.v1i2.440

[8] Nurisusilawati, \& Subagyo. (2016). Penentuan Strategi Saluran Distribusi Berdasarkan Karakteristik Produk Sukses. Forum Teknik, 37(1), 49-57.

[9] Porogoi, V. D., Kaunang, W. P. J., Mantjoro, E. M., Kesehatan, F., Universitas, M., \& Ratulangi, S. (2019). Hubungan Antara Peran Juru Pemantau Jentik Dengan Perilaku Keluarga Dalam Pemberantasan Sarang Nyamuk Demam Berdarah Dengue Di Kelurahan Ranotana Weru. Kesmas, $8(6), 560-567$.

[10] Putri, M. A., Rosmayani, \& Rosmita. (2018). Analisis Faktor - Faktor Yang Mempengaruhi Saluran Distribusi Usaha Kecil Menengah (UKM) (Survei Pada Kue bangkit "Syempana” Di Kota Pekanbaru). Jurnal Valuta, 4(2), 116-137.

[11] Soetanto, M. M. (2015). Rancangan Sistem Distribusi Pada CV Putra-Putri Di Jombang. Jurnal Ilmiah Mahasiswa Universitas Surabaya, 4(1), 1-22.

[12] Solikhin, I., Sobri, M., \& Saputra, R. (2018). Sistem Informasi Pendataan Pengunjung Perpustakaan (Studi kasus: SMKN 1 Palembang). Jurnal Ilmiah Betrik, 9(03), 140-151. https://doi.org/10.36050/betrik.v9i03.40 